\title{
Marx's theory of capital in the history of economics: Marx's concept of capital, classical school, Austrian School, and growth theory
}

\section{Kiichiro Yagi ${ }^{1}$ (D)}

Received: 8 October 2020 / Accepted: 8 December 2020 / Published online: 12 January 2021

(C) Japan Association for Evolutionary Economics 2021

\begin{abstract}
This was originally written in mid-2018 to celebrate the 200-year anniversary of Karl Marx's birth. Its aim is to identify the position of Marx's theory of capital in the history of economics. Thus, this article discusses Marx's critical reception of his predecessors and the investigation after him. In this respect, Hicks' distinction of capital theoreticians between "fundists" and "materialists" is useful. Marx's view of capital shows several fundist characteristics in line with the classical economists preceding him. However, viewed from the materialistic perspective of capital theory, he had successors in the Russian planners of socialist centralized economy in the twentieth century. The peculiarity of Marx's capital theory lies in its critical dimension, which supersedes the positivistic theorizing of ordinary economists. Marx would recognize the relationship of production that emerges out of the antagonistic split between subjective and objective elements ("primitive accumulation"). Thus, we must now ask if two centuries of mankind's history has discovered a solution or made any progress in this respect.
\end{abstract}

Keywords Marx's capital theory - Three moments of capital · Coexisting labor · Reproduction view $\cdot$ Fundist and materialist $\cdot$ Primitive accumulation

JEL Classification B13 · B14 · D24

Kiichiro Yagi

yagi@econ.setsunan.ac.jp

1 Setsunan University, Neyagawa, Osaka, Japan 


\section{Three moments that compose Marx's concept of capital}

What place does Marx's theory of capital occupy in the history of economics? ${ }^{1}$ One difficulty in answering this question is that his theory of capital has plural dimensions, so it is hard to briefly summarize. As most people know, Marx's lifework, Capital, has the subtitle A Critique of Political Economy. This means that his theory of capital is located both on a positive dimension, but also on a critical dimension. Here, we are not using the term "positive" and "critical" in the sense of the author's political attitudes. We use this pair to suggest the level of reflection-whereas "positive" denotes a flat description of the term such as a definition of, or generalization about phenomena, "critical" means the quest for the essence that is revealed by reflection.

From the past to the present, most researchers stayed in the domain of positivist science and refrained from entering the "critical" dimension due to their fear of speculation. Thus, at first, on the level of a simple comparison of capital theories, we must remain in the positive dimension of the historical development of economic science. However, we hope that by reflecting on the historical constellation of theoretical development, we will be able to attain the critical dimension of this discipline as a social science.

In his first draft of System of the Critique of Political Economy that Marx wrote in the year of $1857,{ }^{2}$ he presents a summary of his concept of capital with three moments.

The third moment to be developed in the formation of the concept of capital is original accumulation as against labor, hence the still objectless labor visà-vis accumulation. The first moment took its point of departure from value, as it arose out of and presupposed circulation. This was the simple concept of capital; money on the direct path to becoming capital; the second moment proceeded from capital as the presupposition and result of production; the third moment posits capital as a specific unity of circulation and production. (Relation between capital and labor, capitalist and worker itself [posited] as a result of the production process.) (Marx 1973, p. 319) ${ }^{3}$

We paraphrase them in reference to the arguments in his later work, Capital (Marx 1867, 1885, 1894). The first is "the simple concept of capital; money on

\footnotetext{
1 This article focuses on theoretical aspects of Marx's theory. For an overview of the intellectual history of Marx researchers (Marxologen) in the twentieth century, see my another writing (Yagi 2019).

2 This manuscript is named Grundrisse der politischen Ökonomie. It is available at present in MEW 42 (Marx 1983) as well as MEGA II/1.1-2 (Marx 1976-1981).

3 In German original: "Das dritte Moment, das zu entwickeln ist in der Formung des Begriffs des Kapitals, ist die ursprüngliche Akkumulation der Arbeit gegenüber, also auch die gegenstandslose Arbeit der Akkumulation gegenüber. Das erste Moment ging aus der Wert, als aus der Zirkulation herkommend und sie voraussetzend. Es war der einfache Begriff des Kapitals; das Geld wie es unmittelbar zum Kapital fortbestimmt wird; das zweite Moment ging von Kapitals vor der Produktion und Resultat derselben aus das dritte Moment setzte das Kapital als ein bestimmte Einheit der Zirkulation und Produktion."(Marx 1983, S. 253).
} 
the direct path to becoming capital" (Marx 1973, p. 319). This is the definition of capital or "the general formula for capital" (Marx 1967, p. 153), as seen from the sphere of circulation corresponding to $M-C-M$ ' from the fourth chapter in the first volume of Capital on the transformation of money to capital. The increase in value provides money with the motivation of investment, thus transforming money into capital. With this element, capital is conceived as having "selfexpanding value" (ibid., p. 152).

However, this remains an abstract concept of capital because the realization of the transformation of money into capital does not take place without leaving the sphere of circulation to enter the sphere of production. The second moment proceeds "from capital as the presupposition and result of production." This is the definition of capital in its substantial aspect. Capital is not only the value that transforms itself into the subjective and objective elements of the production process, but also the reproduced value destined for further production. Marx understood the substance of capital in its various forms in such a precondition as well as a result of the circulation of capital. This substantial dimension of Marx's concept of capital has commonalities with the classical economics from François Quesnay and Adam Smith to David Ricardo and John Stuart Mill. It is in this substantial aspect that the normal level of comparison in capital theory between Marx and other economists is made. We would regard such a comparison as remaining in the positive dimension of theory of capital.

Next comes the revelation of class relations within the concept of capital. "The third moment to be developed in the formation of the concept of capital is original accumulation as against labor, hence the still objectless labor vis-à-vis accumulation." Marx envisaged in the preconditions, as well as in the results, of the capitalist system of production the accumulation of capital in monetary form on one side and the mass of laborers on the other-laborers that cannot live without selling their labor power due to their separation from the means of production. He called this "the original accumulation that is opposed to labor" and regarded it as the unified result of production and circulation of capital. Historically, the "original accumulation" (ursprüngliche Accumulation) is the antecedent to proper capitalist accumulation. However, this division is reproduced by the latter in an enlarged scale. The "original accumulation" of capital, i.e., the division of the subjective and objective conditions of production, represents the class relations that are reproduced by the total process of circulation and production under the hegemony of capital. In Marx's view, the "third moment posits capital as a specific unity of circulation and production," as we quoted before.

A glance into the conclusive part of the first volume of Capital, we can at once see that Marx kept this moment as his core insight of his analysis of the capitalist production. He named the historical process or the reorganization of the subjective and objective elements of production "primitive accumulation." (Marx 1967, p. 668).

The capitalist system pre-supposes the complete separation of the labourers from all property in the means by which they can realise their labour. As soon as capitalist production is once on its own legs, it not only maintains 
this separation, but reproduces it on a continually extending scale. (ibid., p. $668)^{4}$

\section{Marx's reproduction view of capital}

\subsection{Hodgskin and Ramsay in theories of surplus value}

Marx's Theories of Surplus Value occupies a considerably large portion of the manuscript that he wrote between 1861 and 1863 in 23 notebooks. When he began writing this manuscript, he would continue A Contribution to the Critique of Political Economy (Marx 1970), which had been published in 1859 (Marx 1859) as the first and second chapter (on commodity and money, respectively) of the first book on capital in the frame of his uncompleted master work, System of a Critique of Political Economy. Critical commentaries on previous literature appeared in this manuscript because Marx was following the style of Contribution in which critical assessments of preceding literature appeared in each chapter. Thus, we can regard the commentary part of the 1861-1863 manuscript as his assessment of previous literature on the theory of capital. Indeed, it was Marx himself that named this commentary "theories of surplus value" - indicating that its main theme is nothing other than capital, since the exploitation of surplus value was, in Marx's view, the essential function of capital.

Naturally, the main literature that Marx examined in his 1861-1863 manuscript commentary consists of classical authors such as François Quesnay, Adam Smith, David Ricardo, and Ricardian economists. This corresponds to the second moment of capital concept, its substantial element being wages and the means of production. Was there anyone among those authors listed in this manuscript who anticipated the third critical moment of capital? In the final part of the manuscript, we find several sections that deal with opponents of capital as an advance (e.g., Thomas Hodgskin and others), skeptics of the function of wage capital (e.g., George Ramsay and Antoine E. Cherbuliez), and a historical critique of capital (e.g., Richard Jones).

Hodgskin is most clear in his devastating criticism of the concept capital which was prevalent among classical economists. He rejected the claim of capitalists for profit by denying the existence of the accumulation of workers' necessaries in the hands of capitalists. He considered wage goods as the product of the "coexisting labor" of fellow workers. To him, it was only a trick of money that workers were assumed to depend on capitalists to acquire their subsistence in the form of wages. He further applied this "coexisting labor" perspective to the materials and instruments for production. Thus, "the effects attributed to a stock of commodities, under the name of circulating capital, are caused by coexisting labor"

\footnotetext{
${ }^{4}$ In German original: "Das Kapitalverhältniss setzt die Scheidung zwischen den Arbeitern und dem Eigentum an den Verwirklichungsbedingungen der Arbeit voraus. Sobald die kapitalistische Produktion einmal auf eignen Füssen steht, erhält sie nicht nur jene Scheidung, sondern reproduciert sie auf stets wachsender Stufenleiter.”(Marx 1867, S. 700).
} 
(Hodgskin 1825, p. 9; Cited in Marx 1963-1971, Pt.3, p. 268; Man. 867). Hodgskin denied the advance view of circulating capital held by classical economists. Marx summarizes this criticism in his own words:

[Raw] cotton, yarn, fabric, are not only produced one after the other and from one another, but they are produced and reproduced simultaneously, alongside one another. What appears as the effect of antecedent labor, if one considers the production process of the individual commodity, present itself at the same time as the effect of coexisting labor, if one considers the reproduction process of the commodity, that is, if one considers this production process in its continuous motion and in the entirety of conditions, and not merely an isolated action or a limited part of it. There exists not only a cycle comprising various phases, but all the phases of the commodity are simultaneously produced in the various spheres and branches of production. (Marx 1963-1971, Pt. 3, p. 279; Man.866)

In this reproduction view, the temporal sequence in the production of individual goods is replaced by a synchronized relationship of parallel production. Here, we must pay attention to the shift of Marx's viewpoint from the production of individual goods to the total process of reproduction. The advance view of capital, in the form of both wage goods and productive goods, seems to be inevitable in the individual production process and disappears when one grasps the entire production process and its reproduction of the preconditions for individual production.

However, Marx noticed that Hodgskin's criticism remained as a naïve negation of the significance of capital. Marx admitted that the real dominance of capital over labor in their direct relationship in the individual process of production included the purchase of labor as a commodity. Workers cannot buy their necessaries directly from their fellow workers with the product of their labor. They can only do so after receiving first from capitalists (i.e., employer) a draft (i.e., money); "a draft moreover which the capitalist is entitled to issue only thanks to the worker's past, present or future product” (ibid., 293; Man. 877). Wage labor is the ground for the mystification of the conditions of reproduction in the form of capital. In his critical comments on Ramsay (1836), who would separate wages as circulating capital from other means of production, he wrote:

What Ramsay overlooks is that if the means of subsistence of the workers did not confront them as "capital" (as circulating capital, as he calls it), neither would the objective conditions of labor confront them as "capital", as "fixed capital", as he calls it. (ibid., p. 328; Man.XVIII-1086)

In one word:

Capital-that is, the social form of the means of reproduction assumed on the basis of wage-labor. (ibid.)

This is Marx's most peculiar viewpoint, which is alien to bourgeois economists that took wage labor, and the employer's right of appropriation of the product of 
that labor, for granted. It goes only one step further from the negation of "accumulation by capitalists" to attain to the secret of "original accumulation," i.e., not the accumulation from production but the antagonistic split of the subjective and objective elements of production, which is the precondition for capitalist relations of production.

Marx's another criticism on Hodgskin consist in his relative neglect of the significance of the objective element, the material means of production. To Marx, "the stage of the development of the productivity of labor...comprises not only the skill and capacity of the worker, but likewise the material means which this labor has created and which it daily renews" (ibid., p. 294; Man. 877). As capital, it takes the form of constant capital, of fixed capital in particular. However, a problem may arise here-whether the synchronized view of reproduction is applicable to the reproduction process using fixed capital.

We have seen that the whole of production presupposes the simultaneous reproduction of the required constituent parts and product in their different forms as raw materials, semi-manufactured goods, etc. But all fixed capital presupposes future labor for its reproduction and for the reproduction of its equivalent, without which it cannot be reproduced. (ibid., p. 292; Man. 876)

We will return to this problem when we consider the determination of the labor value of the product of capitalist production.

\subsection{Consequences of reproduction view}

Marx's critical commentaries on Hodgskin and others revealed his dualistic view of production. Marx did not adopt the classical "advance" view of capital, at least in reference to wage capital (i.e., variable capital), and assimilated Hodgskin's concept of "coexisting labor" in his total reproduction framework covering simultaneous production processes of all interrelated trades and industries. But this perspective did not deny the view of the individual production process in which new commodities are produced by bestowing fresh labor on materials with the help of the productive apparatus (i.e., fixed capital). In this advance view, a single stream that flows through an individual branch of production is the characteristic feature, while parallelism prevails in the reproduction view.

The shift from the individual production process to the total reproduction process is also clear in the first manuscript of volume 2 of Capital (Circulation Process of Capital), written in 1865. In the planned third chapter, "Circulation and Reproduction," Marx sketched a picture of the entire reproduction process in a subsection entitled "Parallelism, Stage Following, Upward Line, Circulation of Reproduction Process (Parallelismus, Stufenfolge, Aufsteigende Linie, Kreislauf der Reproductionsprocesses)" (Marx 1988a, b, MEGA, Abt. II. Bd.4-1, S. 363).

Because the total process of production is the same with the process of reproduction, the reproduction of products goes in all of their various phases at the same time. What is characteristic here is the continuity of the synchroniza- 
tion, continuity of going side by side, or parallelism of all processes of production. They may retain the relations of domination and subordination, or mutual dependence of their products. (My translation) ${ }^{5}$

In this first draft of the Circulation Process of Capital, Marx makes a few significant remarks on several elements of his theory on the process of reproduction.

The first is that not only parallel production, but the replenishment of productively consumed elements in due time, i.e., before the start of the reproduction, is necessary (ibid., S. 367; Man. I-143). This presupposes the temporal coordination of the circulation of capital in both value as well as material.

The second is the flexibility in the amount and the "changeability" in the material form of capital in its reproduction. Evidently, this flexibility/changeability exists within a given limit, but it is important to understand the reproduction process as an adaptation process run by the profit motive of capitalists (ibid., S. 369; Man. I-145).

The third is that the consumption of individuals is also an inevitable intrinsic element of the reproduction process seen in total (ibid., S. 370; Man. I-283). This is not confined to the consumption of workers that reproduces the labor force of workers, but also the consumption of non-workers, including capitalists. Both are necessary for the circulation of the total economy.

Marx admitted the reformulation of the concept of value together with this shift in perspective from production to reproduction. From the viewpoint of the latter, the value of commodities is determined not by the quantity of the embodied labor, but the quantity of socially necessary labor required for their reproduction.

The definition of value by the necessary labor hours embodied in a commodity alters to, or receives a further definition, that its value is determined by the (socially) necessary labor hours for its reproduction when the production process as a whole is considered. What determines the value of commodities is not the labor hour necessary for their production but that for their reproduction, so far as they are not sold immediately, or the process of circulation gives enough time for a deviation between the bestowed quantity of labor and the quantity for their reproduction to emerge. (My translation) ${ }^{6}$

\footnotetext{
${ }^{5}$ In German original: Weil der Gesamtproductionsproceß zugleich Reproductionsproceß ist, gleichzeitig Reproduction der Producte in allen ihren verschiedenen Phasen statt. Das Charakterische ist hier die fortwährende Gleichzeitigkeit, das beständige Nebeneinanderlaufen oder der Parallelismus aller Productionsprocesse, welches Verhältniß der Ueber und Unterordnung oder wechselseitigen Abhängigkeit ihre Producte zu einander haben mögen. (Marx 1988a, MEGA Abt. II 4-1, S. 368; Man. I-143).

6 In German original: Die Bestimmung des Werths durch die in einer Waare enthaltene nothwendige Arbeitszeit ändert sich, oder bestimmt sich weiter, wenn der Reproductionsproceß als Ganzes betrachtet wird, dahin, daß ihr Werth durch die zu ihrer Reproduction (gesellschaftlich) notwendige Arbeit bestimmt ist. Es ist nicht die Arbeitszeit, nöthig um Waare zu producieren, sondern die, sie zu reproducieren, die ihren Werth bestimmt, sobald sie nicht gleich verkauft wird, oder ihr Circulationsproceß Zeit genug läßt für die Abweichung des in ihr enthaltnen Quantums und des zu ihrer Reproduction nothwendigen Quantums Arbeit (Marx 1988a, b, MEGA Abt. II. 4-1, S. 271f.; Man. I-81.).
} 
This passage echoes Michio Morishima's argument on Marx's dual definition of value, i.e., embodied labor and socially necessary labor. ${ }^{7}$ In his modern interpretation of Marx's theory of value, while the former is determined by simultaneous equations that are now known as Dmitriev equations, the latter is derived as the sum of labor inputs required to obtain one unit of net product as counted by Leontief's input-output equations. If Morishima's interpretation is correct, socially necessary ${ }^{8}$ labor signifies the sum of coexisting labor, as maintained by Hodgkin. Can this passage support Morishima's argument? To our regret, judging from the text in which the cited passage is found, we must say no. The advanced determination of value from the viewpoint of reproduction in the cited passage signifies only socially necessary labor for new production.

Here, it should be noted that Marx had come very close to anticipating such "socially necessary labor" as Morishima posited. Marx had the view of reproduction that plural production processes run in parallel. His failure to apply simultaneous equations to the determination of value prevented him from making forward progress and the task was therefore left for his successors.

However, reproduction, too, needs time. The production periods of various branches differ. The period of selling and purchasing must also be considered. Furthermore, as previously mentioned, fixed capital, such as machines and buildings, endure longer than the production period of the product concerned. In the first 1865 draft of the second book of Capital, as well as in its present version edited by Friedrich Engels, the common linear depreciation method was adopted. The text cited above is also found in a section discussing the reproduction period of fixed capital. From the viewpoint of the original embodied definition of value, fixed capital adds a part of its value during each production period of the product concerned. However, from the viewpoint of reproduction, its estimated value for its future replacement differs from its past original value. Here, Marx did not miss the arbitrary and flexible nature of the evaluation of the reproductive value of fixed capital. ${ }^{9}$

\footnotetext{
7 Marx's Economics (Morishima 1973, p. 11). While the first corresponds with the additional view of past labor embodied in the means of production and the present labor, the second represents the sum of the labor input in all of the related branches of production to acquire one net product of the commodity concerned.

8 The meaning of "socially necessary" is delicate. While the text in the first chapter of Capital explains it as "the labor-time .... that required to produce an article under the normal conditions of production, and with the average degree of skill and intensity prevalent at the time" (Marx 1967, p.47), "socially" in the level of circulation and reproduction implies the wider perspective of the production system as a whole.

9 Marx's model of the circuit of capital consists of three forms of capital (financial, productive, and commercial capital) and three processes corresponding the formers (purchase, production, and sales). The analysis of this circuit model with time lags was first explored by Foley (1986) and then further investigated by Mori (2004).
} 


\section{Criticism of Marx and capital theory}

\subsection{The decline of the classical concept of capital?}

When Marx was writing Capital, John Stuart Mill's Principles of Political Economy was the standard work of classical economics. Mill adopted from his predecessors the view of capital as an "accumulated stock of the produce of labor" to support the production and to maintain productive labor (Mill 1848, Book 1, Chap. 3) and placed it in an early equilibrium view based on supply and demand analysis. In the fourth chapter of Principles, Mill surmised his view on capital in the following several "fundamental propositions":

(1) Industry is limited by capital

(2) An increase in capital gives increased employment to labor, without assignable bounds

(3) Capital is the result of savings and all capital is consumed

(4) Capital is maintained by perpetual reproduction, as shown in the recovery of countries from devastation (ibid., Chap.4)

The foundation of these propositions is the notorious theory of capital as "wages fund," although Mill admitted its increase and restoration by accumulation and reproduction. In a lecture to the General Council of the First International Workingmen's Association, Marx refuted the negative view of the wage struggle grounded in this theory. ${ }^{10}$ Although his opponent, John Weston, was not a scholar but a veteran Owenist, Marx had to convey the results of his long-continued investigation in plain language. Of course, he stressed workers' resistance against wage cuts and long working days. He supported their demand for wage hikes during phases of increased productivity. In Marx's view, the labor movement is directly related to the production and distribution of "surplus value." Although Marx maintained the classical concept of "wages fund" under the name "variable capital," its true significance is rooted in its relationship with "surplus value."

Hicks (1974) classified theories of capital in the history of economics into the camp of fundists and that of materialists. The former regard the essence of capital in the value invested in production, since merchants see in their commodities the funds that they invested in their purchase. Economists who stress original inputs (i.e., labor or land, or both) and regard capital as an intermediate product on the way to the final products belong to the camp of fundists.

Hicks considered most classical economists, including Marx, fundists. This naming is like the term "advance" view of capital in our usage. The latter, materialists, considers capital goods as real entities that can serve production process (and thus, indirectly, serve consumption). The value of capital goods is derived from their service in production or consumption, not from the value (or labor) bestowed upon

10 Value, Price and Profit delivered on 20 and 27 June 1865 at the General Council of the International Workingmen's Association. The original manuscript is in Marx (1988b) (MEGA II 4.1, S. 385-432). 
them. In Hicks's view, most modern neo-classicists since Léon Walras and Alfred Marshall were materialists for whom capital meant the physical capital goods themselves, particularly production facilities. This view is solid and strict in so far as each individual capital good is specified and measured in material units. The strictest materialist is probably John von Neumann, who postulated that every durable means of production transforms itself into the same productive means, one-period senior capital goods, and integrated them into the process of joint production. However, in most cases, when materialists deduce any meaningful result from their analysis, they aggregate all individual capital goods into one unit, $K$, to constitute the productive function together with aggregated labor, $L=P(K, L) .^{11}$

The decline of the classical concept of capital began with Mill's so-called recantation of the wage-fund doctrine in 1869. After 2 years, William St. Jevons and Carl Menger published their books, which were based on the value determination of marginal utility. However, despite the proximity in years, the shift from fundism to materialism is not the same as the move from the classical to the neoclassical school. Jevons (1871) retained the fundist view in conceiving the transformation of "free capital" into real capital. Even Marshall (1890) was ambiguous in this respect. ${ }^{12}$ A significant stream of fundism that survived through the twentieth century is the Austrian capital theory postulated by scholars like Eugen von BöhmBawerk and Friedrich Hayek. This school focused their attention on the time structure of the production process. It is no coincidence that Böhm-Bawerk has emerged as the most prominent critic of Marx in the history of economics. Therefore, we will now compare Böhm-Bawerk and Marx in terms of their conceptions of capital and time in the following section.

\subsection{The time structure of capital}

In 1894, in his open criticism of Marx, Böhm-Bawerk highlighted the inconsistencies between labor value in the first volume of Capital and production price in its third volume. Marxists would defend their master by arguing that the surplus value in the first volume is transformed into profit, or total labor value into aggregate prices, with a general rate of profit in the third volume. Since then, many ideas have been provided to solve the so-called "transformation" riddle. ${ }^{13}$

Böhm-Bawerk had good reason to challenge Marx's theory of value and capital. In the mid of 1980s, Takashi Negishi discussed Böhm-Bawerk's criticism of Marx in the relation of his time preference (Zeitagio) theory of interest. ${ }^{14}$ Negishi found that Böhm-Bawerk had already, in 1884, criticized Marx in History and Critique

\footnotetext{
11 The criticism against the materialist view was raised in the mid of the twentieth century by Piero Sraffa and Joan Robinson. Despite the significance of this "capital controversy" fought by two Cambridgeans, we won't discuss it from the reason that Marxian view is not concerned in this controversy.

12 As Marshall (1890) explained formation of capital with the concept of "waiting," we can apply our discussion on the Austrian understanding of the interest to him, too. See Yagi (1992).

13 See relevant chapters in Hunt and Schwarz (1972) in this respect.

14 Negishi (1980, 1985, 1986). Negishi referred Weizäcker (1973) further.
} 
of Interest Theories (Böhm-Bawerk 1983). ${ }^{15}$ In this book, Böhm-Bawerk criticized Johann C. Rodbertus's surplus (Rente) theory together with Marx's surplus value theory and posited that the exploitation of surplus value is not validated when the identity of goods at a different time is not assumed. Böhm-Bawerk's own theory of interest, the theory of the premium of time, was presented in the sequel, Positive Theory of Capital (1889), which, together with the aforementioned work, comprises Böhm-Bawerk's lifework, Capital and Interest (Kapital und Kapitalzins) (1884-1889). ${ }^{16}$

Present productive goods, including labor, produce consumable goods only after time has elapsed. Therefore, the former must endure a discount in value compared with the acquisition of the latter. In other words, those that can provide present consumable goods can acquire a premium compared with those who can have them only in the future. ${ }^{17}$ This premium emerges as the profit of capitalist (employer) when he provides workers (employee) the present consumable goods as wage. Then, the relationship between capitalists and workers changes from that of exploitation to that of an exchange of present goods for future goods. Böhm-Bawerk argued that, if the preference of present (consumable) goods to future goods is positive, it can explain a positive rate of interest on present capital.

Such an explanation of exchange with a time preference signifies Böhm-Bawerk's characteristic neo-classicalism. However, Böhm-Bawerk was a fundist that considered production to be a time-consuming process (roundabout production) promoted by the original input of labor and understood capital as the total of intermediate products in that process. He regarded capital as an "intermediate product" that exists during the process of roundabout production. It is the provisional result of the labor input that remains in the production process for a certain time. Thus, in his view, capital has two elements-labor and time. In its simplest version, the quantity of capital of a production process consists of the sum of each labor input multiplied by the time spent (i.e., stay period) in the production process. Böhm-Bawerk devised a measure of the capital intensity of a production process by inventing the index of "average production period." 18 Simplest version of this index-the average weighted by the stay period-is not valid in the case of the compound interest rate. If such a time index was possible, it would represent the magnitude of capital and could function as a version of the neo-classical production function in the form of $P(L$, Average production period).

\footnotetext{
15 Basic elements of his interest theory appeared in his early manuscript of 1876 (Böhm-Bawerk 1983) already. It contained his explanation of the exchange between worker and his employer from the viewpoint of time preference. But Marx was not referred in this early work.

16 Translated into English by William Smart in 1890 and 1891 respectively. Both are now available as a kindle edition, amazon.com (Böhm-Bawerk 1890, 1891).

17 Böhm-Bawerk (1891) mentioned three causes for the emergence of time preference, i.e. differences in want and provision for want, underestimate of the future, and the technical superiority of present goods.

18 Böhm-Bawerk's simplest version of "average production period" is valid in case of simple-interest model but not in case of compound interest model.
} 


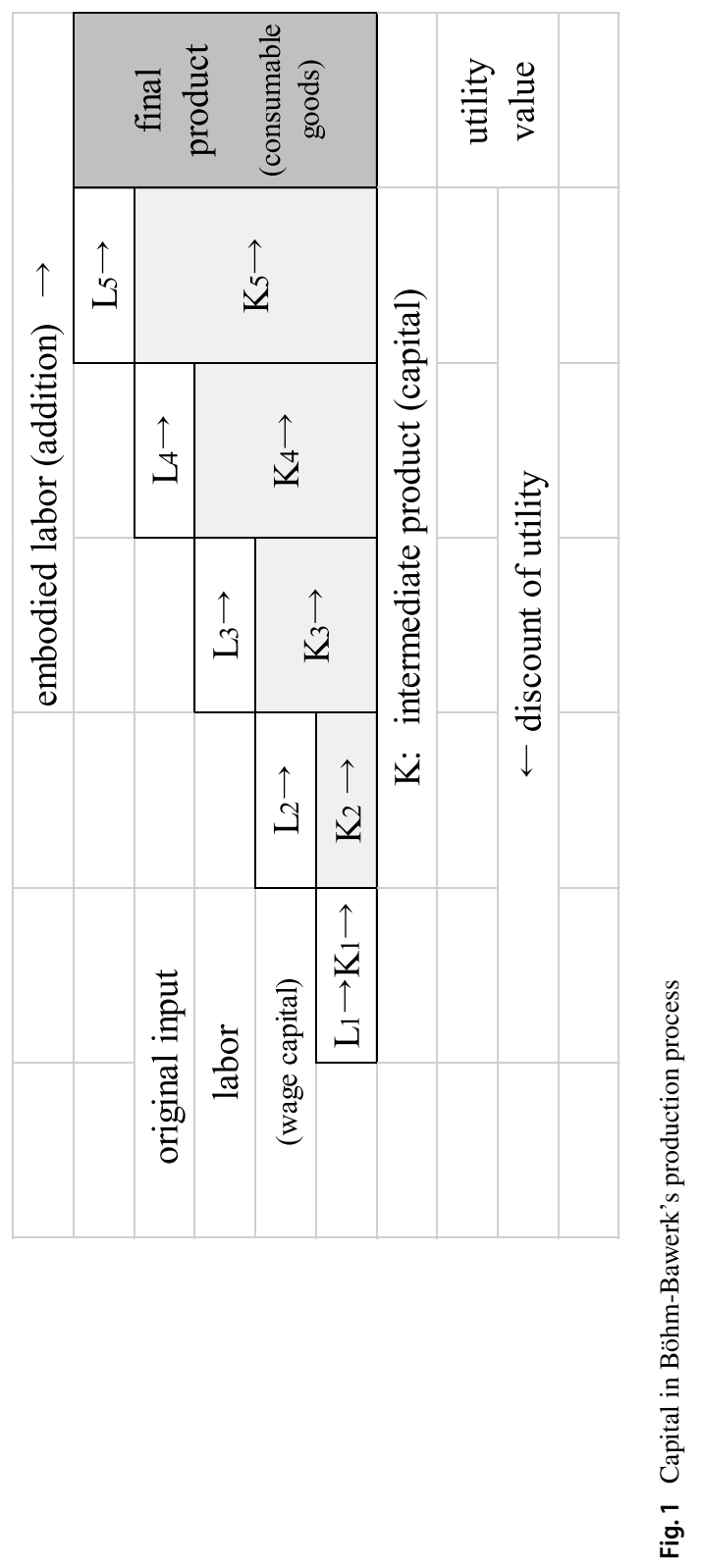


The production process that Böhm-Bawerk conceived is illustrated in Fig. 1 with an example of the five-stage production model. Labor input $1(L 1)$ at the beginning of Stage 1 will become the final product after five stages of production. Additional labor input in the Stage 2 (L2) becomes the final product after four stages. $L 3$ after three stages, $L 4$ after two stages, $L 5$ after one stage. When we see the process in relation to the inputs of labor and capital, the last stage of production (Stage 5) consists of intermediate product $K 5$ and labor $L 5$. $K 5$ is the product of $K 4$ and $L 4$ from the previous stage. $K 4$ is the product of $K 3$ and $L 3, K 3$ of $K 2$ and $L 2$, and $K 2$ is one stage senior to $K 1$, which is the direct result of the original labor input, $L 1$.

Classical economists as well as Marx viewed production as a combination of labor and material inputs (i.e., the means of production). In the scheme shown in Fig. 1, the latter is decomposed into the input of labor and the intermediate product produced in the previous stage. Thus, the final product is the result of the series of labor inputs in all preceding stages. In the case of Fig. 1, these are L1, $L 2, L 3, L 4$, and $L 5$. Since the material inputs (i.e., intermediate product) in every production decline as we back track through each stage of production, viewing the entire production process as a cumulative series of labor inputs over the whole stage is also possible. In Fig. 1, the simple version of the labor value theory adds them together and maintains the sum as the embodied labor in the final product: $L 1+L 2+L 3+L 4+L 5$.

However, Ricardo already noticed in his Principles (Ricardo 1817) that the lapse of time inevitably modifies a simple labor value theory, since the capital bestowed in the previous period requires compensation, assuming that the profit rate is positive. If we follow Ricardo's suggestion, denoting the general profit rate as $\boldsymbol{r}$, the modified labor value should be:

$$
\boldsymbol{L} 1(\mathbf{1}+\boldsymbol{r})^{5}+\boldsymbol{L} 2(\mathbf{1}+\boldsymbol{r})^{4}+\boldsymbol{L} 3(\mathbf{1}+\boldsymbol{r})^{3}+\boldsymbol{L} 4(\mathbf{1}+\boldsymbol{r})^{2}+\boldsymbol{L} 5(\mathbf{1}+\boldsymbol{r}) .
$$

If we take the Austrian view that neither the means of production nor labor has an independent value as such but both derive their value from the final product that can appeal to consumers and thus acquires value based on their marginal utility, the value of the preceding intermediate product as well as the labor input must be discounted for the time interval required to obtain the final consumable product. If we use discount rate $\rho$, the value attributed to labor input $L 5$ (wage) and material capital input (K5) is the subjective value (i.e., marginal utility) of the final product, divided by $(1+\rho)$. By further operation of discount, we receive a series of discounts by $(1+\rho)^{2},(1+\rho)^{3},(1+\rho)^{4}$, and $(1+\rho)^{5}$. Böhm-Bawerk's interest theory considers this discount rate to be the interest rate, that is, $r=\rho$.

Negishi approved of Böhm-Bawerk's criticism that Marx's theory of exploitation assumed an ungrounded identification of goods at different times. Although he admitted that such identification could only prevail in a strict, stationary economy such as in the case of simple reproduction, he declared that so long as a surplus exists, an economy begins growth that violates such an identification. However, Negishi's logic is purely neo-classical in the sense that he denied any structural relationship with the surplus in society and forgot that the source of accumulation is also the surplus that flows into the capitalist class as the profits of capital. 
If we adopt the reproduction view as suggested in the previous section, all the labor inputs to the system of production appear simultaneously. The problem shifts from the difference of time to that of the difference of labor in various related production branches. In this respect, Marx assumed the tendency toward the equalization of skills and the universalization of the working force under capitalism as the essential foundations for the formation of a united working class. Then, we can assume the same (daily) wage for workers in all branches and assume the same length of a working day. This implies the same rate of surplus value (or rate of exploitation) holds in all production branches. The theory of labor value can function as a system of prices (value price) that compensates all labor inputs equally and guarantees reproduction at the same size. As long as the extended input matrix including wage (variable capital) is productive, there exists surplus labor and surplus products. However, these two surpluses are the result of the conditions in which the daily consumption of workers is fixed from the beginning.

Negishi suggested that reproduction with a surplus inevitably triggers growth, under which the command of present goods enables an increased amount of future goods. He maintained that this undermines the validity of the labor theory of value. We can reject this criticism by adopting the reproduction view of value theory. We can use the labor value theory to judge the rate of exploitation (i.e., the rate of distribution) independently from the wage-profit (interest) rate frontier and without interfering in price formation under this choice. As Piero Sraffa's $\boldsymbol{w}-\mathbf{r}$ frontier suggests, production with a surplus itself shows only the possibility of the choice of distribution (Sraffa 1960). But such a dualistic view introduces the problem of explaining the relationship of the value system and the price system and interlinking the key figures of both-exploitation rate and profit rate, surplus value and profit, and total value and total price.

Since Morishima and Seton (1961), it has been known that on the von Neumann path of optimal growth in which all branches of production grow at the same rate, the postulates of the so-called transformation problem-i.e., (1) profit rate in value term $=$ profit rate in price term, (2) total value $=$ total price, and (3) total surplus value $=$ total profit - hold. In this steady-state growth path, the price of every product must guarantee the increased input of the same growth rate. In optimal growth, the growth rate equals the profit rate $\left(g^{\mathbf{m a x}}=r\right)$. This equality reflects the necessity of reproduction, since, in the case of extended reproduction, reproduction requires an increased amount of input, not the same amount.

\section{Growth theory and capital}

\subsection{From capital theory to macroeconomics}

The progress of capital theory in the twentieth century was mainly achieved in terms of materialism. Walras considered capital substantially as durable capital goods that have no relationship with labor or wages. Capital is the source of revenue, the value of which is derived from capitalization of the revenue (net profit). On the market of capital goods, this valuation on the demand side and the production cost on the 
supply side are equalized. However, capitalization requires a positive interest rate. To fulfill this precondition, Walras formulated an imaginary commodity $\boldsymbol{E}$ that promises the owner perpetual net revenue. If the total income of a society surpasses its total consumption and the difference between the two flows into savings in the form of purchases of the commodity $\boldsymbol{E}$, it encourages positive savings, which stimulates the growth of the economy and disturbs the equilibrium (Walras 1954). Hicks (1939) solved this problem by postulating a succession of temporary equilibria.

In the fundists camp, Wicksell (1936) integrated Böhm-Bawerk's capital theory into the Walrasian equilibrium analysis. Although Wicksell added the use of land in parallel to labor as the original inputs, his theory of capital structure was essentially a refined version of Böhm-Bawerk's capital theory. On the assumption of a given amount of capital, progress in technology, which usually requires the lengthening of the production period, results in a decrease in annual capital investment, thus decreasing the demand for labor. If technological progress goes hand-in-hand with accumulation, the result depends on the combination of the positive effect of the increase in capital and the negative effect of capital deepening. Hayek applied this Austrian theory of capital structure (i.e., Hayek's triangular figures) to explain the process of prosperity and the crisis caused by introducing ungrounded optimism during a phase of prosperity. ${ }^{19}$

John Maynard Keynes did not delve deeply into capital theory. It is unknown if he fully read Marx's Capital. However, he did know and converse with a circle of Marxists (e.g., Maurice H. Dobb) and others deeply impressed by Marx (e.g., Sraffa and Joan Robinson). In his manuscript for the General Theory, Keynes cited Marx's $\boldsymbol{M}-\boldsymbol{C}-\boldsymbol{M}$ ' formula to inspire his retreat from the orthodox classical view. ${ }^{20}$ Remember that the first moment of capital in Marx's view was "money on the direct path to become capital." Money represents not only the effective demand but also yields interest when its service is provided. In Hicks's view, Keynes was not exempt from the materialist conception of capital; however, those Keynesians that would not adopt the production function and favored the use of the capital coefficient in their analysis of growth theory are fundists.

\subsection{The experience of socialism}

The materialist concept of capital probably better suits a planned economy that was liberated by the owner's interest than a capitalist economy. In distributing scarce resources to the multitudes that need them, rationing is generally recognized as one of the most practical alternatives to a competitive market with fluctuating prices. As Otto Neurath dreamed at the rationing office of the short-lived revolutionary

\footnotetext{
19 Hicks's neo-Austrian capital theory (Hicks 1973) is a macro synthesis of the circulating capital model and fixed capital model. The continuous input-point output structure of the former model and the point input-continuous output structure of the latter model is integrated in the model of continuous inputcontinuous output structure.

20 Keynes (1979), p.81.
} 
government in Bavaria (Neurath 1925), the wartime experience of a delegated economy under World War One (WWI) nourished the belief in the possibility of a planned economy without having the market managed by a circle of technologyoriented intellectuals. Ludwig von Mises (1935) and Hayek (1935) criticized them and argued that such a collectivist economy would inevitably fail due to the lack of rational calculation. This debate is well known and the prevalent view at present is in favor of the critics.

Compared with the Western debate on the economic calculation under socialism, the efforts of Soviet Russian economists are not widely known. In the preface of an anthology of the mathematical economics of Russian and Polish economists published in Moscow during the age of Khruschchov, Nemchinov (ed. 1964) highlighted the Balance Tables of National Economy for the years 1923/24 as an early achievement of Russian economists. ${ }^{21} \mathrm{He}$ regretted that the honor of creating input-output analysis has been attributed to Wassily Leontief who left Russia in 1925. Nemchinov's Balance Tables were the work of practical statisticians, not of theoretical economists.

Nemchinov further appreciated the sub-table of the balance of productive instruments and investments, which consisted of key relationships in macroeconomic analysis. Although revolutionary Russia during the lively years of the 1920s produced a creative growth theorist such as Grigory Feldman, ${ }^{22}$ the political repression under Stalin's regime suffocated any original economic thought. Originality survived only in the stream of mathematical economists and statisticians leading the investigation into central planning.

In the economy of the Union of Soviet Socialist Republics (USSR), or Soviet Russia, since all large industries were state-owned and the distribution sector was also public, the transaction of productive goods were executed without any change in ownership, except for the transaction between the state and cooperatives (Kolkhoz). Formally, the state sector's productive goods were not commodities with prices representing compensation for their transfer. Commodities remained only in the transaction between the state and cooperatives and in the final purchase of consumer goods by individuals. However, because Rubles remained the means of exchange for the transaction, both factory managers as well as Gosplan planners used it as a tallying measure.

Soon planners and economists realized that a rational price system was necessary for any consistent planning. The discussions first started in the age of ambitious growth but suffocated under the terror of the Stalin age. After Stalin's death, it was revived and continued until the Kosygin reform era. Of course, many dogmatic Marxian economists adhered to the use of Marxian labor values in the planning economy. But it had a fatal defect in coping with growth. First, it could not cope with the distribution of scarce resources. Second, it did not correspond with the necessity of reproduction on a wider scale. For the industrialization of such a large but backward nation, the scarcity of improved capital goods was a serious problem.

\footnotetext{
21 Nemchinov ed. (1964) Introductory chapter.

22 See Domar (1957), chap. 9.
} 
Russian economists repeatedly discussed how to distribute investment throughout various sectors to attain rapid growth and sought appropriate efficient criteria for this purpose.

Extending Marx's concept of socially necessary labor expenditure (SNLE) to the production system of the entire national economy, Novozhilov $(1964,1972)$ proposed a modified concept of differential SNLE as the modified value that enabled optimal planning. In terms of the (1) substitutability of the means of production among various production processes, (2) differences of efficiency in their various uses, and (3) relative scarcity in relation to demand, it was assumed that the use of superior productive goods in some sectors inevitably caused a feedback effect on costs for other sectors. Other sectors would have to endure incremental labor inputs, compared with the case in which superior goods should not be used in the above sector. Novozhilov argued that planners who evaluated the production variants from the viewpoint of optimal growth should add this increment to real expenditures for the production sector concerned.

With such a modification of the SNLE concept, the modified value informs the price, considering the rent from the different conditions of land and the emergence of a general profit rate in the capitalist economy.

When there is high level and rate of growth of the productive forces then in each unit of production not only the best but also less effective means of production are utilized. Then, socially necessary expenditure is not determined by an average quantity expended on the production of the given goods but by the increment of labor expended on the whole final social product, required for the production of the given goods. (Novozhilov 1972, p. 389).

Novozhilov found a resemblance between his concept of modified value (i.e., differential SNLE) and the capitalist economy's production price. Both result from the quest for the most efficient use of scarce resources (Novozhilov 1964). Their difference lies in the conscious application in planning and the unintended outcomes of the quest for higher rentability.

In a growing economy, a necessary condition of expanded reproduction is the provision and acquisition of an increased amount of the means of production and an increased input of labor. If the growth rate is $g$ percent, then the price of a product must guarantee a profit rate not less than $g$ percent, all other conditions remaining the same. From the perspective of the labor theory of value, the SNLE under extended reproduction must count a $g$ percent increase in labor input. Negishi limited the possibility of the labor value theory in the case of simple reproduction and denied it in the case of extended reproduction. Our view is that a modified concept of value (i.e., SNLE) that guarantees the reproduction of the system is desired in the case of extended reproduction. ${ }^{23}$

In the West, where economic backwardness was less pervasive, the postulates of reproduction were treated purely as a theoretical problem of growth theory. von Neumann formulated the optimal equilibrium growth path of a multi-sector economy

${ }^{23}$ See the appendix to chapter 8 in Dobb (1969). 
considering the use of fixed capital with the joint production of one-period senior capital goods as early as 1932. Although his original German paper was published in 1938, it was only after the publication of its English translation in The Review of Economic Studies (von Neumann 1945) that his original idea was added to the common stock of theoretical economists. ${ }^{24}$ On this path, all sectors grow simultaneously, staying in proportion to constant prices.

Michio Morishima developed an analysis of a growing economy by improving von Neumann's equilibrium growth theory. He proved that the so-called "transformation problem" is solved in the case of a price system on this equilibrium path (Morishima and Seton 1961). In 1973, he published Marx's Economics, in which he recommended Marxian economists to adopt the optimal value derived from the inequality system. Although many articles were published on the duality of value (or price) systems and the quantity system, Morishima's view was generally considered to be the culmination of theoretical debates on Marx's value and price theories at the end of the 1970s.

This overview is biased since we have focused on the temporal dimension of capital in relation to the Marxian concept of reproduction. If we shift our focus to distribution as Sraffa did it in his 1960 book, Production of Commodities by Means of Commodities, a different scene may emerge. However, we can conclude the story of capital theory in the twentieth century as revolving around the duality between quantity systems and value systems in the process of reproduction. This dimension is better understood now as compared with the discussion that took place during the nineteenth century.

\section{Reproduction of the "original accumulation"}

The last problem remaining is regarding the third moment of capital, a concept that we introduced in the first section. It is the reproduction of "the original accumulation" of capital against labor. First, we have to pay attention to the fact that Marxian concept of original accumulation is totally different from the classical concept of "previous accumulation" as stipulated by Adam Smith (1776). As a typical classical fundist, Smith thought that previous accumulation must exist to form capital as an advance. Since he did not adopt the synchronized view of reproduction, he had to suppose that capitalists accumulated their capital by their own work and thrift. However, Marx, in the chapter on original accumulation in the French edition of Capital, cited a poetic style dialog from Johann Wolfgang von Goethe on the origin of a family's assets that traced back to a theft (prise). ${ }^{25}$ In such case, the praise for diligence and thrift is too childish. Thus, whether the ultimate origin might be savings or theft, the starting point is the division of the subjective and objective elements

\footnotetext{
24 von Neumann(1945). Sraffa (1960) adopted von Neumann's joint production approach in his treatment of the fixed capital. Hicks (1965) surmised the progress of growth theory after von Neumann.

25 Marx (1872) p. 314. Marx cited from Goethe's poetry "Catechisation” (Goethe 1850, S. 276).
} 
of production under the hegemony of capital. As French Structuralists maintained (Althusser and Balibar 1971), it's not the historical continuity but its rupture that the quest for the "origin" of the capitalist production relations reveals us. We have already discussed in the second section that it is not the past act that entitles one to the receipt of revenue, but it is the structure and condition of reproduction that determines the value and price.

In Marx's intellectual development this concept had its origin in the concept of "alienation of labor." In his 1844 manuscript, known as Economic and Philosophic Manuscript, young Marx depicted the three- or fourfold alienation of workers under capitalism, i.e., alienation of the labor itself, of the product of labor, of the speciescharacter and of the relations with others. (Marx 1959, 1982) As the causation between these three or four aspects of alienation was not discussed, not the historical sequence but the structural relation of the alienation in its totality was the problem to Marx. When Marx identified this relation of alienation and appropriation as the production relation under capitalism that reproduces itself perpetually, his critical investigation into the political economy of capitalism began.

Marx's lifework Capital is devoted to reveal the mechanism of this alienation and appropriation. In its volume 1, it explains the accumulation of capital on the ground of the exploitation of surplus value. The contrast of accumulation of capital and the misery of the exploited class was realistically described. However, it was also in this part that the "original accumulation" was placed in Marx's theoretical system and the possibility of the social and cooperative production was told. He described it as the reestablishing of the "individual property based on the acquisition of the capitalist era: i.e., on co-operation and the possession of land of the means of production." (Marx 1967, p.715) ${ }^{26}$ In the volume 2 (Marx 1885), the socio-economic structure of capitalism is described from the viewpoint of reproduction. This volume is dedicated to reveal the mechanism that the split of subjective and objective elements of production is maintained via the circulation of capital. It is in this volume that Marx's peculiar view of capital takes full-fledged theory of socio-economic reproduction: the original condition of capitalist production ("original accumulation") is reproduced and maintained in the ever-growing scale.

However, Marx's Capital provided us with the veil that tends to cover the reality and shows the superficial relations in the surface. The exchange of capitalists and workers in the sphere of circulation keeps the feature of voluntary transactions of the legally equal agents. As Thomas Hodgskin realized, this is the trick of "money" (wage) that hides the exploitative nature of production relations under capitalism. Further, under the influence of the asset holders' way of thinking, the labor (labor power) is lined along with capital and land as an origin of revenue (wage in this case). As Marx intended to start the last part of volume 3 of Capital (Marx 1894) with the sarcasm on the "trinity formula" that sacralizes capital, land, and labor as

\footnotetext{
${ }^{26}$ In German original: "Diese stellt das individuelle Eigenthum wieder her, aber auf Grundlage der kapitalistischen Aera, der Cooperation freier Arbeiter und ihren Gemeineigenthum an der Erde und den durch die Arbeit selbst producierten Produktionsmitteln.” (Marx 1867, S. 745).
} 
the holy origins of revenues in a bourgeois society, even workers may be trapped in the illusion of the equal holders of private assets.

Apparently, it was rather difficult for ordinary academic economists to deal with the theory of capital from Marx's third critical viewpoint. After the emergence of marginal productivity analysis in the late nineteenth century, neo-classical economists neglected the production relations between capital and labor and tended to consider profit and wage separately. Their destination is the trinity formula of assets and their revenues.

They may have concerns over the situation of working class and seek for solutions to remedy it. However, apart from the brave attempts of socialists, anarchists, or syndicalists, recommendation of neo-classical economists generally remains in the level of distribution. After two centuries from Marx's birth, at least in the advanced economies, the real wage has risen considerably, and the labor distribution ratio is considered as one of the key variables that can influence the general economic condition of the countries concerned.

Problems of distribution is only one element of the modern capitalism. From the viewpoint of capital theory, the constant capital, or means of production are the base on which labor realizes its productivity. In the contemporary understanding, wage is usually considered as cost and seldom considered as capital. Means of production, constant capital in Marxian term, such as machinery, equipment, fabricated or rare materials, patents, know-hows, etc., and the command over them are decisive in the modern production process of capitalism. The recovery of the harmony between subjective and objective elements of production needs the vision that overcome the alienation of those means of production from the hands of workers.

In this respect we would mention a unique Japanese economist that contributed to widen the perspective of political economy of capitalism in the Marxian sense. Shigeto Tsuru studied at Harvard in 1930s under Joseph A. Schumpeter together with Paul Samuelson and Paul Sweezy. After his return to Japan, he not only occupied the central position in the economics academia between the revived Marxian economics and the introduction of Western modern economics, but also kept considerable intellectual influence in the post-1945 Japanese politics.

In 1959, he circularized several questions on the status quo of the post-war capitalism among prominent economists and published their answers with his concluding article in Japanese (Tsuru ed. 1959) and in English (Tsuru ed. 1961). Tsuru's questions as well as his conclusion were unique, as he maintained the path of mixed economy in which the economic surplus is socialized in wider extent. He proposed the socialization of surplus flow instead of the socialization of stock (capital). It was a roundabout way to conquer capitalism that fit the advance of welfare state.

Another valuable insight Tsuru provided was the appreciation of the material aspect of the human economy that was often hidden under the surface of exchangeable value. Facing serious environmental deteriorations in the late stage of the rapid growth era of Japan, he expanded the perspective of socio-economic reproduction to the material circulation and the natural environment. He applied his idea of the "socialization of flow" to the problem of pollution and proposed pollution tax. This proposal was to him a step forward to recover the harmony between the material aspect and the value aspect of the production and consumption. (Tsuru 1971). 
Compared with the socialization of ownership and the introduction of central planning, Tsuru's proposals may sound too mild and gradual. However, in our view, he was one of the rare economists that applied Marx's critical ideas to the contemporary problems.

\section{Concluding remarks}

One of the most significant lessons of the twentieth century is that neither collective ownership nor central planning were successful in overcoming of the split between the subjective and objective elements of production. To the contrary, people in the so-called socialist countries suffered severe alienation due to the monopolization of control over production as well as the pressure of their publicly admitted ideology. The split of the subjective element and the objective element under capitalism was dissolved into the coercive unity under the omnipotent state. Indeed, the socialist economic system, characterized by collective ownership and central planning, replaced capitalism for several decades in a number of countries. A new pattern of primitive accumulation occurred for the state occupied by nomenklatura. Nonetheless, it could not excel to the level of performance of advanced capitalism. It is now clear that, at best, collective ownership and central planning are, with appropriate use, auxiliary tools for the improvement of economic governance. ${ }^{27}$

On the other hand, Tsuru's proposal of the "socialization of surplus," too, did not advance smoothly. While welfare expenditure has continued to rise, considerable portion of the public control over the financial activity has been abolished under the name of "deregulation." An international race to the bottom appeared in the corporate taxation. Under the name of "neo-liberalism," a strong adverse intellectual tide that rejects any public control over business activities influenced politicians and businessmen as well. However, the global financial crisis in 2008 as well as the present COVID-19 pandemic crisis may contribute to the change of the tide in economic policies.

Another very significant lesson for the solution of Marx's third moment of capital is that we cannot neglect the natural backgrounds of capitalist production. Both the subjective and the objective elements of the production exist in the material world of the nature. External effect always accompanies with the private economic activities of production and consumption. Due to the expansion of the resource wasting economic activity, the environmental deterioration has become a global problem. A narrow view of the objective element of production in the form of the means of production does not suffice for the recognition and solution of the split under capitalism. A wider view is also necessary to understand the subjective element, i.e., labor as the activity of living men and women. Labor or work consists of two natural capabilities of human beings: the intellectual capability and the physiological nature. Under the modern conditions of labor, we should take the stress on both capabilities seriously.

\footnotetext{
27 On the discussions and the process of the "transition" from the regime of planned economy to market economy, see Yagi (2020).
} 
According to the traditional ideas of socialism and communism, ownership has been considered as an exclusive legal command over tangible or intangible resources. However, real utilization of the resources depends on the knowledge, skill, and the cooperation of agents concerned. Thus, not the legal form of property but the forms of the command of knowledge and skill and of the cooperation are more important for the solution of the alienated antagonistic relations between subjective and objective elements of production (i.e., the reestablishment of "individual property"). In this respect, the recovery of science and technology, which are at present in the hands of big business and of the closed academic circles under the ruling authority, back to the hands of people is significant. Not the economic or political power, but the democratic cooperation of the people can solve the split of the subjective and objective element of production including nature in and out of the both elements.

Performance of capitalism differs considerably between countries. Some advanced countries have succeeded in enhancing the well-being of their workers. As long as the means of production and products are owned by employers (i.e., capitalists) and the surplus is appropriated by them as profit, the split between the subjective and objective elements of production is inevitably reproduced. Since investment is financed by profit, the volume of investment ultimately determines the level of profit. The condition of workers depends on the decisions of investors. This split is institutionalized in the form of the corporation, which is really the personification of profit-seeking capital. If this situation should continue, the third moment of capital would not change. However, as we mentioned Tsuru's idea of "socialization of the surplus," the democratic control of the surplus may alter this situation.

But the one-sided view of the economy from the perspective of capital might be erroneous, or incomplete at best. As Marx conceived a book on labor as a sequel to Capital, modern capitalism required a countervailing viewpoint from the subjective element of production, or that of labor. The subjective element of production is not powerless. The knowledge and skill of workers are crucial for firms in competition. Workers also require advanced means of production, which is the embodiment of the collective knowledge of humanity to exert their skills and creativity. They can also unite themselves to present their demands to management and negotiate through collective bargaining on several levels. Furthermore, they can influence business through legislation, governance, and other public institutions. Under the taxation system, the surplus is, as Tsuru maintained, already being socialized at least partly.

Capital, whose essence lies in profit-seeking, naturally seeks a way to repress the demands of workers and evade public control. Capitalist firms would eventually develop their activity in greenbelts within borders and beyond them. Internationally they would move to a new frontier where they could enjoy more freedom. However, while capital is no more than the alienated labor in the form of self-expanding value, labor represents the living activity of human being. Thus, the latter is dominant everywhere in reality at any time. The task is to develop the way of cooperation on the ground of the achievement of human species in the science and technology including management and culture. 
The real investigation into the third moment of capital, i.e., the split of the subjective and objective elements of production, or the alienation of labor, is not a speculative task. It is true that this perspective must be widened so as to contain the natural base or backgrounds of production, consumption, and the livelihood of the people. The liberty of individuals in the modern world is not assured without their control over the objective elements and knowledge and intelligence as the common social stock embodied in capital. In the first section, I asserted that the third moment of capital belongs to a reflective dimension. As the final word of this historical reflection on the concept of capital, I would posit that it is the common task of all human and social sciences to assess the present situation of this fundamental split in the contemporary age that has transformed itself widely since Marx's and seek a better way to cope with it. In this cooperative task, I hope that economics can contribute through the analysis and exploration of the reproductive process of the subjective and objective elements of production, which is, at present, understood in the form of capital.

Acknowledgements The author appreciates comments of discussants at several academic meetings in 2018 and 2019. Special thanks is directed to anonymous reviewers of this journal, under whose suggestion the $5^{\text {th }}$ section was added to the original manuscript.

\section{Compliance with ethical standards}

Conflict of interest The author states that there is no conflict of interest.

\section{References}

Althusser L, Balibar É (1971) Lire le Capital. Nouvelle édition. Maspero, Paris

Böhm-Bawerk EV (1890) Capital and interest: a critical history of economic theory Transl. by William A. Smart. MacMillan, London

Böhm-Bawerk EV (1891) Capital and interest: the positive theory of capital. Transl. by William A. Smart. Macmillan, London

Böhm-Bawerk EV (1983) Böhm-Bawerk's first interest theory with Carl Menger-Böhm-Bawerk correspondence 1884-1885. In: Yagi K (ed) Study series of social science literature, 3. Hitotsubashi University, Tokyo

Dobb M (1969) Welfare economics and the economics of socialism. Cambridge University Press, Cambridge

Domar ED (1957) Essays in the theory of economic growth. Oxford University Press, New York

Foley DK (1986) Understanding capital: Marx's economic theory. Harvard University Press, Cambridge Goethe JWV (1850) Sämtliche Werke, Bd.2, J. G. Cotta, Tübingen

Hayek FV (1935) The nature and history of the problem. In: Hayek FV ed, Collectivist economic planning. Routledge, London, pp 1-40

Hicks J (1939) Value and capital: an inquiry into some fundamental principles of economic theory. Clarendon Press, Oxford

Hicks J (1965) Capital and growth. Clarendon Press, Oxford

Hicks J (1973) Capital and time: a neo-Austrian theory. Clarendon Press, Oxford

Hicks J (1974) Capital controversies: classics and moderns. Am Econ Rev 64:307-316

Hodgskin T (1825) Labour defended against the claim of capital. Mechanics' Magazine, London

Hunt EK, Schwartz JG (1972) A critique of economic theory. Penguin Education, Harmondsworth

Jevons WS (1871) The theory of political economy. Macmillan, London

Keynes JM (1979) Collected works of John Maynard Keynes, vol 29. Macmillan, London

Marshall A (1890) Principles of economics. Macmillan, London 
Marx K (1859) Zur Kritik der politischen Ökonomie. Franz Duncker, Berlin

Marx K (1959) Economic and philosophic manuscripts of 1844. Economica 26(104):379

Marx K (1867) Das Kapital. Kritik der politischen Ökonomie. Bd. 1: Der Produktionsprocess des Kapitals. Otto Meissner, Hamburg

Marx K (1872) Le Capital. Traduction de M J Roy. Maurice Lachatre, Paris

Marx K (1885) Das Kapital. Kritik der politischen Ökonomie. Bd. 2: Der Zirkulationsprozess des Kapitals. Hrsg. v. F. Engels. Otto Meissner, Hamburg

Marx K (1894) Das Kapital. Kritik der politischen Ökonomie. Bd.3 : Der Gesamtprozess des Kapitals. Hrsg. v. F. Engels. Verlag Otto von Meissner, Hamburg

Marx K (1963-1971) Theories of surplus value: the fourth volume of capital. 3 Parts. Progress Publishers, Moscow

Marx K (1967) Capital. A critical analysis of capitalist production. Translated from the third German edition by Samuel Moore and Edward Aveling and edited by Frederick Engels, volume 1. Progress Publishers, Moscow

Marx K (1970) A contribution to the critique of the political economy. In: Edited by Dobb M and translated from German (Marx 1959) by S. W. Ryazanskaya. International Publishers, New York

Marx K (1973) Grundrisse: Foundations of the Critique of Political Economy (Rough Draft). Translated with a Foreword by Martin Nicolaus. Penguin Books in association with New Left Review, Hammondworth

Marx K (1976-1981) Ökonomische Manuskripte 1857-1858 (Grundrisse der politischen Ökonomie). MEGA (Marx-Engels Gesamtausgabe) Abteilung II, Band 1, Teil 1, 1975. Teil 2, 1981. Dietz Verlag, Berlin

Marx K (1982) MEGA (Marx-Engels Gesamtausgabe) Abteilung I. Bd.2. Dietz Verlag, Berlin

Marx K (1983) Grundrisse der Kritik der politischen Ökonomie, Hrsg. V. Institut für Marxismus-Leninismus beim ZK der SED. MEW (Marx-Engels Werke) 42. Dietz Verlag, Berlin

Marx K (1988a) Ökonomische Manuskripte 1863-1867, Text Teil 1. MEGA, Abteilung II. „Das Kapital“ und Vorarbeiten, Band 4. Dietz Verlag, Berlin.

Marx K (1988b) "Value, price and profit", value, price and profit delivered on 20 and 27, 1865 at the General Council of the International Workingmen's Association. In: Marx, pp 385-432.

Mill JS (1848) Principles of political economy: with some of their applications to social philosophy. John W. Parker, London

Mises L (1935) Economic Calculation in the Socialist Commonwealth. In: Hayek FA ed, Collectivist economic planning. Routledge, London, pp 87-130. [Original in German "Die Wirtschaftsrechnung im sozialitsischen Gemeinwesen," Archiv für Sozailwissenschaften. Vol.47, 1920].

Mori K (2004) Shihon to Jikan no Seiji-Kenzaigaku (Political economy of capital and time). Hassakusha, Tokyo

Morishima M (1973) Marx's economics: a dual theory of value and growth. Cambridge University Press, Cambridge

Morishima M, Seton F (1961) Aggregation in Leontief matrix and the labour theory of value. Econometrica 29(2):203-220

Negishi T (1980) Marx and Böhm-Bawerk in the Theory of Interest. Economie et Societé (Presse Universitaires de Grenoble) 14:287-304

Negishi T (1985) Economic theories in a non-walrasian tradition. Cambridge University Press, Cambridge

Negishi T (1986) Marx and Böhm-Bawerk. Econ Stud 37(1):2-10

Nemchinov VS ed (1964) The use of mathematics in economics. English ed. ed. by A. Nove. Oliver \& Boyd, Edinburgh [Russian original: Нумчнова ВС Ред. Применение Математики в Зкономических исследованиях, Москва,1959]

Neumann JV (1945) A model of general economic equilibrium. Rev Econ Stud 13(1):1-9 [German original: "Über ein ökonomisches Gleichungssystem und eine Verallgemeinerung des Browerschen Fixpunktsatzes." Ergebnisse eines Mathematischen Seminar, edited by K. Menger, Vienna 1938]

Neurath O (1925) Wirtschaftsplan und Naturalrechnung. E. Laub, Berlin

Novozhilov VV (1964) Cost-benefit comparisons in a socialist economy. In: Nemchinov VS (ed), pp 33-190

Novozhilov VV (1972) The problem of planned pricing and the reform of industrial management. In: Nove A, Nuti DM eds (1972), Sociaslist economics. Penguin Education, Hammondsworth, pp $378-397$

Ramsay G (1836) An essay on the distribution of wealth. A. and C. Black, Edinburgh 
Ricardo D (1817) On the principles of political economy, and taxation. John Murray, London

Smith A (1776) An inquiry into the nature and causes of the wealth of nations. W. Strahan and T. Cadell, London

Sraffa P (1960) Production of commodities by means of commodities. Cambridge University Press, Cambridge

Tsuru S (ed) (1959) Gendai Shihonshugi no Saikento. Iwanami, Tokyo

Tsuru S (ed) (1961) Has capitalism changed?: An International symposium on the nature of capitalism. Iwanami, Tokyo

Tsuru S (ed) (1970) Environmental disruption: proceedings of international symposium. International Social Science Council, Tokyo

Walras L (1954) Elements of pure economics, translated by W. Jaffé. Allen \& Unwin, London

Weizäcker CC (1973) Modern capital theory and the concept of exploitation. Kyklos 26(2):245-281

Wicksell K (1936) Interest and Prices, translated by R. F. Kahn. Macmillan, London [German original: Geldzins und Güterpreise, Jena: Gustav Fischer, 1898]

Yagi K (1992) Marshall and Marx: 'waiting' and 'reproduction.' Kyoto University Economic Review 62(2):32-42

Yagi K (2020) System transition and the institutional political economy. In: Yagi K (ed) From reproduction to evolutionary governance, Chap 6. Springer Japan, Tokyo, pp 113-130

Yagi K (2019) MEGA and the unhappy institutionalization of marxology in the twentieth century. In: Trautwein HM (ed) Studien zur Entwicklung der ökonomischen Theorie XXXIV (Schriften des Vereins für Socialpolitik, Band 115/XXXIV), S.19-43

Publisher's Note Springer Nature remains neutral with regard to jurisdictional claims in published maps and institutional affiliations. 